\title{
Whole body protein kinetics during hypocaloric and normocaloric feeding in critically ill patients
}

\author{
Agneta Berg ${ }^{1,2}$, Olav Rooyackers ${ }^{1}$, Bo-Michael Bellander ${ }^{2}$ and Jan Wernerman ${ }^{\text {1* }}$
}

\begin{abstract}
Introduction: Optimal feeding of critically ill patients in the ICU is controversial. Existing guidelines rest on rather weak evidence. Whole body protein kinetics may be an attractive technique for assessing optimal protein intake. In this study, critically ill patients were investigated during hypocaloric and normocaloric IV nutrition.

Methods: Neurosurgical patients on mechanical ventilation $(n=16)$ were studied during a 48-hour period. In random order 50\% and 100\% of measured energy expenditure was given as IV nutrition during 24 hours, corresponding to hypocaloric and normocaloric nutrition, respectively. At the end of each period, whole body protein turnover was measured using d5-phenylalanine and 13C-leucine tracers.
\end{abstract}

Results: The phenylalanine tracer indicated that whole-body protein synthesis was lower during hypocaloric feeding, while whole-body protein degradation and amino acid oxidation were unaltered, which resulted in a more negative protein balance, namely $-1.9 \pm 2.1$ versus $-0.7 \pm 1.3 \mathrm{mg}$ phenylalanine $/ \mathrm{kg} / \mathrm{h}(P=0.014)$. The leucine tracer indicated that whole body protein synthesis and degradation and amino acid oxidation were unaltered, but the protein balance was negative during hypocaloric feeding, namely $-0.3 \pm 0.5$ versus $0.6 \pm 0.5 \mathrm{mg}$ leucine $/ \mathrm{kg} / \mathrm{h}$ $(P<0.001)$.

Conclusion: In the patient group studied, hypocaloric feeding was associated with a more negative protein balance, but the amino acid oxidation was not different. The protein kinetics measurements and the study's investigational protocol were useful for assessing the efficacy of nutrition support on protein metabolism in critically ill patients.

Keywords: Protein synthesis, Protein degradation, Amino acid oxidation, Parenteral feeding

\section{Introduction}

Feeding critically ill patients in the ICU is a controversial subject in many respects. Timing of feeding, caloric content, and protein content are all issues, and here, existing guidelines are based upon a low level of scientific evidence [1-3]. Why? Published studies are old, and often used obsolete techniques to evaluate the effects from feeding [4]. While physiology is unchanged, treatment (intensive care medicine) has changed, and this limits the validity of studies from the last millennium.

Nitrogen balance constitutes the classic measurement of protein intake effects. Limitations of the classic nitrogen balance technique are particularly pronounced in intensive care although most limitations are general.

\footnotetext{
* Correspondence: jan.wernerman@karolinska.se

${ }^{1}$ Department of Anesthesiology and Intensive Care Medicine, K32, Karolinska University Hospital Huddinge, Stockholm 14186, Sweden

Full list of author information is available at the end of the article
}

While control over intake and output may be sufficient, the steady-state criterion and adaption-to-intake criterion (both critical for interpretation of data) are rarely fulfilled. Meticulously performed nitrogen balance studies, however, form the foundation for current recommendations [5,6]. Reports from body composition studies are also part of the documentation behind current recommendations. Techniques based on impedance measurements are not reliable in critically ill patients (associated with rapid changes in body fluids). Neutrone activation is a very attractive technique to assess lean body mass [7] but low availability - and need for patient transfer for assessment - limit its usefulness. So far, no randomized prospective studies of protein intake in ICUs are available.

Whole body, protein kinetics measurements that use isotopically labeled amino acid should be the technique

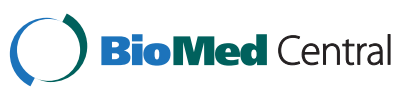


of choice for global assessments of protein metabolism in relation to protein intake. Protein synthesis and degradation can be assessed separately, and amino acid oxidation and whole-body protein balance can be calculated. The period during which a steady state is needed is relatively short, and measures may be repeated. Despite these obvious benefits - at least in theory - only a few studies of critically ill patients are available [8-10]. There are relatively more studies in burn patients [11,12], but the validity of these studies for trauma and sepsis patients in general ICUs is limited.

In this pilot study, we included a homogenous patient group in a neurosurgical ICU. To optimize study conditions, we limited inclusions to sedated, mechanically ventilated adult patients, who received only parenteral nutrition. This selection, of course, limits the generalizability of results. Our main objective was to compare hypocaloric and normocaloric feeding in terms of whole-body protein kinetics.

\section{Materials and methods}

Patients admitted to the neurosurgical ICU at Karolinska Solna were studied in the 2009 to 2011 period. Inclusion criteria were (i) a diagnosis of traumatic brain injury or intracranial bleeding, (ii) sedated and on mechanical ventilation, and (iii) receiving parenteral nutrition. Exclusion criteria were (i) age $<18$ years, and (ii) absence of informed consent. The Ethics Committee of Karolinska Institutet approved the protocol and the patients' relatives gave informed consent after being informed verbally and in writing about the investigational procedure and possible risks.
The protocol included a 48-hour study period, starting with an energy expenditure measurement by indirect calorimetry during feeding (Deltatrac Metabolic Monitor, Datex-Ohmeda, Helsinki, Finland). Thereafter, patients were randomized to one of two alternatives, namely, to receive (i) $50 \%$ of the measured energy expenditure during 24 hours before receiving 100\% during the consecutive 24 hours, or (ii) $100 \%$ of the measured energy expenditure during 24 hours followed by $50 \%$ of the measured energy expenditure during the next 24 hours. This protocol enabled patients to be their own controls, provided the two consecutive days were comparable (Figure 1).

Nutrition was delivered as an all-in-one formulation: Nutriflex Lipid Special (B Braun AG, Melsungen, Germany) contains a protein-to-energy ratio of $0.049 \mathrm{~g} / \mathrm{kcal}$. The intravenous (IV) nutrition infusion rate was set to give the amount of calories measured as energy expenditure by the indirect calorimetry. In cases when propofol was used for sedation, the IV nutrition infusion rate was adjusted accordingly. So, in practice this further lowered the administered protein-per-kg for most patients.

The whole-body protein turnover measurements were made using isotopically labeled leucine and phenylalanine in parallel. There were two study periods for each patient, at the end of each 24-hour period, with one of the two nutritional regimens.

On each occasion the patients received a primed continuous infusion of the labeled amino acids (Figure 1). The prime consisted of ring ${ }^{2} \mathrm{H}_{5}$-phenylalanine $(0.5 \mathrm{mg} / \mathrm{kg})$, ring ${ }^{2} \mathrm{H}_{4}$-tyrosine $(0.15 \mathrm{mg} / \mathrm{kg}), 3,3-{ }^{2} \mathrm{H}_{2}$-tyrosine $(0.3 \mathrm{mg} / \mathrm{kg})$, $1{ }^{13} \mathrm{C}$-leucine $(0.9 \mathrm{mg} / \mathrm{kg})$ and ${ }^{13} \mathrm{C}$-sodium-bicarbonate
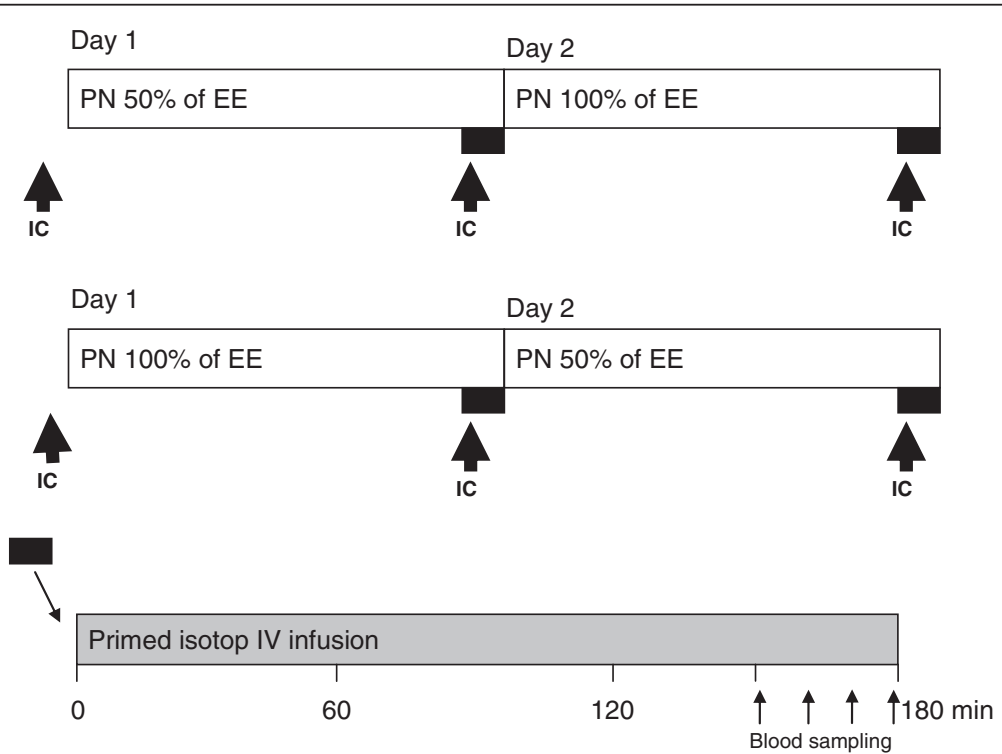

Figure 1 A schematic illustration of the study protocol. IC, indirect calorimetry; EE, energy expenditure; PN, parenteral nutrition; IV, intravenous. 
$(0.2 \mathrm{mg} / \mathrm{kg})$. A continuous infusion of ring- ${ }^{2} \mathrm{H}_{5}$-phenylalanine $(0.5 \mathrm{mg} / \mathrm{kg} / \mathrm{h}), 3,3-{ }^{2} \mathrm{H}_{2}$-tyrosine $(0.3 \mathrm{mg} / \mathrm{kg} / \mathrm{h})$ and $1-{ }^{13} \mathrm{C}$-leucine $(1.0 \mathrm{mg} / \mathrm{kg} / \mathrm{h})$ followed the prime.

All isotopes were obtained from Cambridge Isotopes Inc. (Cambridge, MA, USA). The hospital pharmacy prepared and tested sterile solutions for sterility and pyrogenity. Labeled amino acids were administered intravenously for 150 minutes before the sampling to obtain an isotopic steady state before the sampling period, which involved samples taken on 4 occasions during the last 30 minutes of the infusion. Blood samples were taken from an arterial line. Plasma was obtained and frozen at $-80^{\circ} \mathrm{C}$ until analysis. Breath samples for ${ }^{13} \mathrm{CO}_{2}$ measurements were taken from the DeltaTrac Metabolic Monitor during the 30-minute sampling periods. A Douglas bag was used, and the samples were transferred to vacutainers.

For analysis of the labeled amino acids, plasma was deproteinized using sulfosalisylic acid. The amino acids were cleaned using ion-exchange chromatography and dried using rotary evaporation. The amino acids were derivatized using $\mathrm{N}$-(tert-butyldimethylsilyl)-N-methyltrifluoroacetamide (MTBSTFA). The amino acids were analyzed with an Agilent N5973 gas chromatography and mass spectrometer (GCMS; Agilent, Kista, Sweden) for m/z 336 and 341 for phenylalanine, 302 and 303 for leucine, and 466, 468, and 470 for tyrosine.

Keto-isocaproic acid (KIC) enrichment in plasma was analyzed by deproteinizing the plasma with ethanol and drying the sample by rotary evaporation. KIC was then derivatized with $o$-phenylenediamine - extracted in ethanol and dried again. The dried KIC is derivatized using MTBSTFA and $\mathrm{m} / \mathrm{z}$ of 259 and 260; it is analyzed with GCMS. Amino acid concentrations in plasma were analyzed by high pressure liquid chromatography (HPLC) using on-column derivatization with ortho-phtaldialdehyde/3mercaptopropionic acid (OPA/3-MPA) as described earlier [13]. Breath samples were analyzed for ${ }^{13} \mathrm{CO}_{2}$ using a BreathMat (Thermo Finnegan, Bremen, Germany).

Whole-body rate of appearances ( $\mathrm{Ra}$ ) for phenylalanine and leucine were calculated:

$$
\mathrm{Ra}=\mathrm{I} /\left(\left(\mathrm{E}_{\mathrm{i}} / \mathrm{E}_{\mathrm{A}}\right)-1\right),
$$

in which $I$ is the infusion rate of the tracer and $E_{i}$ and $E_{A}$ are the enrichments in the infusate and plasma respectively. Plasma KIC enrichments were used for leucine $\mathrm{Ra}$ calculation, and $\mathrm{Ra}$ plasma enrichments of ${ }^{2} \mathrm{H}_{5}$-pheylalanine and ${ }^{2} \mathrm{H}_{2}$-tyrosine were used for phenylalanine and tyrosine, respectively. The endogenous rate of appearance (endoRa) was calculated by subtracting the amino acid infusions in the parenteral nutrition from the Ra. Both amino acids are essential, and therefore the
endoRa represents the whole-body protein breakdown rate.

Because these measurements were done in a steadystate situation, the $\mathrm{Ra}$ is equal to the rate of disappearance (Rd). Whole body protein synthesis was calculated by subtracting the oxidation rates for phenylalanine and leucine from the $\mathrm{Rd}$. Oxidation rates for leucine $(\mathrm{Ox})$ were estimated by the appearance of ${ }^{13} \mathrm{CO}_{2}$ in the breath and for phenylalanine by the flux to tyrosine $\left(\mathrm{Q}_{\mathrm{PT}}\right)$. The plasma KIC enrichments were used for the leucine calculations because they better represent the intracellular events [14]:

$$
\begin{aligned}
& \mathrm{Q}_{\mathrm{PT}}=\mathrm{Ra}_{\mathrm{Tyr}} \times\left(\mathrm{E}_{\mathrm{ATyr}} / \mathrm{E}_{\mathrm{APhe}}\right) \times \mathrm{Ra}_{\text {Phe }} /\left(\mathrm{I}_{\text {Phe }}+\mathrm{Ra}_{\text {Phe }}\right) \\
& \text { Leu Ox }=0.8\left(\mathrm{~V}_{\mathrm{CO} 2} \times{ }^{13} \mathrm{CO}_{2 \text { breath }}\right) / \mathrm{E}_{\mathrm{KIC}}
\end{aligned}
$$

in which $E_{\mathrm{ATyr}}$ and $\mathrm{E}_{\mathrm{APhe}}$ are the plasma enrichments of ${ }^{2} \mathrm{H}_{4-}$ tyrosine and ${ }^{2} \mathrm{H}_{5}$-phenylalanine, $\mathrm{I}_{\mathrm{Phe}}$ is the infusion rate of the phenylalanine tracer, $\mathrm{V}_{\mathrm{CO} 2}$ is the $\mathrm{CO}_{2}$ production rate as measured by the DeltaTrac Metabolic Monitor, ${ }^{13} \mathrm{CO}_{2}$ is the enrichment in the breath samples and $\mathrm{E}_{\mathrm{KIC}}$ is the enrichment of ${ }^{13} \mathrm{C}$-KIC in the plasma. The factor 0.8 is to correct for the recovery of ${ }^{13} \mathrm{CO}_{2}$ during the study period [15].

Whole-body protein synthesis rates were estimated by subtracting the Ox from the Rd. Whole-body protein balance was calculated by subtracting protein breakdown (Ra phenylalanine or leucine) from this protein synthesis rate.

Student's $t$-test for paired samples was used for comparing the measurements in the hypocaloric and normocaloric states. The Kolmogorov-Smirnov test was used to test for normal distribution of the data. When applicable (as indicated in the text), Wilcoxon's rank test was applied. A $P$-value $<0.05$ in a two-sided test was considered statistically significant. STATISTICA software (Statsoft, Uppsala, Sweden) was used for calculations. The sample size of 16 subjects was chosen to enable us to combine the two randomized groups into one by only applying a simple non-parametric sign test (8 subjects in each group). In the literature the coefficient of variation for whole-body leucine kinetics in healthy subjects is reported to 3 to $4 \%$ [16].

\section{Results}

Patients $(\mathrm{n}=16)$ with traumatic brain injury or intracranial bleeding were studied. They were sedated, and were on mechanical ventilation and parenteral nutrition. Seventeen patients were recruited into the study, but one patient had to be excluded due to protocol violation in terms of non-adhesion to the nutritional protocol. The mean $( \pm$ SD) age of the patients was $49.5 \pm 10.4$ years. The male/female gender distribution was $11 / 5$ (see Table 1 for other patient characteristics). After 
Table 1 Patient characteristics

\begin{tabular}{|c|c|c|c|c|c|c|c|c|c|}
\hline $\begin{array}{l}\text { Weight } \\
\text { (kg) }\end{array}$ & Diagnosis & $\begin{array}{l}\text { GCS, admission } \\
\text { (score) }\end{array}$ & $\begin{array}{l}\text { Study day } \\
\text { (in ICU) }\end{array}$ & $\begin{array}{c}\text { SOFA } \\
\text { (study day) }\end{array}$ & Survival & Group $^{a}$ & $\begin{array}{c}\mathrm{EE} \\
\text { (kcal/kg) }\end{array}$ & $\begin{array}{c}\text { TPN } \\
\text { (kcal/kg) }\end{array}$ & $\begin{array}{c}\text { Protein } \\
(\mathrm{g} / \mathrm{kg})\end{array}$ \\
\hline \multicolumn{10}{|c|}{ Individual patients } \\
\hline 79 & $\mathrm{TBI}$ & 3 & 17 & 5 & Y & $100 / 50$ & 24.9 & 18.8 & 0.9 \\
\hline 95 & $\mathrm{SDH}$ & 12 & 4 & 9 & N & $50 / 100$ & 23.5 & 23.5 & 1.1 \\
\hline 86 & $\mathrm{SDH}$ & 12 & 4 & 12 & Y & $100 / 50$ & 25.8 & 24.6 & 1.2 \\
\hline 76 & $\mathrm{SDH}$ & 3 & 8 & 9 & Y & $50 / 100$ & 22.4 & 18.4 & 0.9 \\
\hline 85 & $\mathrm{TBI}$ & 6 & 3 & 10 & Y & $100 / 50$ & 27.0 & 25.9 & 1.3 \\
\hline 77 & $\mathrm{ICH}$ & 6 & 10 & 6 & Y & $50 / 100$ & 23.0 & 19.1 & 0.9 \\
\hline 61 & $\mathrm{SAH}$ & 11 & 17 & 7 & Y & $100 / 50$ & 31.3 & 20.3 & 1.2 \\
\hline 78 & $\mathrm{TBI}$ & 6 & 5 & 9 & Y & $50 / 100$ & 24.1 & 24.1 & 1.2 \\
\hline 90 & $\mathrm{SAH}$ & 5 & 5 & 9 & N & $100 / 50$ & 20.6 & 17.0 & 0.8 \\
\hline 64 & $\mathrm{SDH}$ & 5 & 5 & 10 & Y & $50 / 100$ & 25.8 & 16.4 & 0.8 \\
\hline 65 & $\mathrm{EDH}$ & 4 & 4 & 9 & Y & $100 / 50$ & 26.4 & 26.4 & 1.3 \\
\hline 87 & $\mathrm{SDH}$ & 3 & 3 & 3 & Y & $50 / 100$ & 19.9 & 19.9 & 1.0 \\
\hline 89 & $\mathrm{SDH}$ & 4 & 1 & 7 & Y & $50 / 100$ & 28.8 & 28.8 & 1.4 \\
\hline 95 & $\mathrm{TBI}$ & 3 & 5 & 9 & Y & $100 / 50$ & 27.1 & 26.5 & 1.3 \\
\hline 100 & $\mathrm{SDH}$ & 5 & 11 & 7 & Y & $50 / 100$ & 25.7 & 22.5 & 1.1 \\
\hline 85 & $\mathrm{SDH}$ & 8 & 1 & 9 & Y & $100 / 50$ & 18.9 & 15.5 & 0.8 \\
\hline \multicolumn{10}{|c|}{ Full patient sample $(n=16)$, mean values (SD) } \\
\hline 82.0 & NA & 6.0 & 6.4 & 8.1 & NA & NA & 24.7 & 21.7 & 1.1 \\
\hline$(11.5)$ & NA & $(3.1)$ & $(5.0)$ & $(2.2)$ & NA & NA & (3.3) & $(4.1)$ & $(0.2)$ \\
\hline
\end{tabular}

Percent measured energy expenditure (EE) during 24 hours/percent measured EE during the next consecutive 24 hours. TBI, traumatic brain injury; SDH, subdural hemorrhage; $\mathrm{ICH}$, ischemic brain injury; $\mathrm{SAH}$, subarachnoid hemorrhage; $\mathrm{EDH}$, epidural hemorrhage; GCS, Glasgow coma scale; SOFA, sequential organ failure assessment score; EE, energy expenditure; TPN, total parenteral nutrition; $\mathrm{Y}$, yes; N, no; NA, not applicable.

energy expenditure measurement by indirect calorimetry, patients were randomized into the two groups to be studied for 48 hours, namely, hypocaloric before normocaloric, or normocaloric before hypocaloric. Patients were studied on day 6 (range 1 to 17 days) of the ICU stay; when given normocaloric feeding the total parenteral nutrition $(\mathrm{TPN})$ contained $21.7 \pm 4.1 \mathrm{kcal} / \mathrm{kg} / 24$ $\mathrm{h}$ and $1.07 \pm 0.15 \mathrm{~g}$ protein $/ \mathrm{kg} / 24 \mathrm{~h}$ (Table 1 ). For individual patients, part of the energy supply was contained in the sedation given. The two patient subgroups were compared statistically for all variables shown below; no significant differences were observed. In Figures 1 and 2 the two subgroups are indicated.

Indirect calorimetry was repeated three times for each patient; (i) before randomization, (ii) after 24 hours of being given parenteral nutrition (PN) of $100 \%$ of measured EE, and (iii) after 24 hours of being given PN oft $50 \%$ of measured EN (Figure 1). Pre-study EE was $24.7 \pm$ $3.3 \mathrm{kcal} / \mathrm{kg} / 24 \mathrm{~h}$, which was not different from the energy expenditure obtained after being given 24 hours of $\mathrm{PN}$ at $100 \%$ of measured EE, $24.5 \pm 2.3 \mathrm{kcal} / \mathrm{kg} / 24 \mathrm{~h}$, while the measured energy expenditure after being given 24 hours of $50 \%$ of measured EE was $4 \%$ lower at $23.4 \pm$ $2.4 \mathrm{kcal} / \mathrm{kg} / 24 \mathrm{~h}(P=0.049)$. For the respiratory quotient, the pre-study value was not different from the value obtained after being given 24 hours of PN at $100 \%$ of measured EE, $0.80 \pm 0.10$ and $0.82 \pm 0.10$, respectively. On the other hand, after being given 24 hours of $\mathrm{PN}$ of $50 \%$ of measured EE the respiratory quotient was lower at $0.76 \pm 0.01(P=0.005)$ compared to the value obtained after 24 hours of $100 \%$ of measured EE.

Because the amount of protein given was different due to the use of an all-in-one formulation, the free amino acids were measured in plasma. The total sum of free amino acids in plasma did not change significantly, with $2.8 \pm 0.5 \mathrm{mmol} / \mathrm{L}$ versus $2.9 \pm 0.4 \mathrm{mmol} / \mathrm{L}(P=0.085)$ for $\mathrm{PN}$ of $50 \%$ and $100 \%$ of measured $\mathrm{EE}$, respectively.

Insulin administration at the time of protein turnover measurements was recorded retrospectively. Eight patients were not given insulin; the remaining eight patients were given $5.8 \pm 5.0$ (median 4.0) $\mathrm{U} / \mathrm{h}$ when given $100 \%$ of EE, and $3.2 \pm 2.1$ (median 3.5 ) $\mathrm{U} / \mathrm{h}$ when $50 \%$ of EE was given. When all 16 patients are combined the corresponding values are $2.9 \pm 3.8$ (median 1.0) $\mathrm{U} / \mathrm{h}$ and $1.6 \pm 2.7$ (median 0.0$) \mathrm{U} / \mathrm{h}(P>0.05$ (Wilcoxon test) in both calculations).

Whole-body protein turnover was measured during the last 30 minutes of 24 hours of PN, corresponding to 

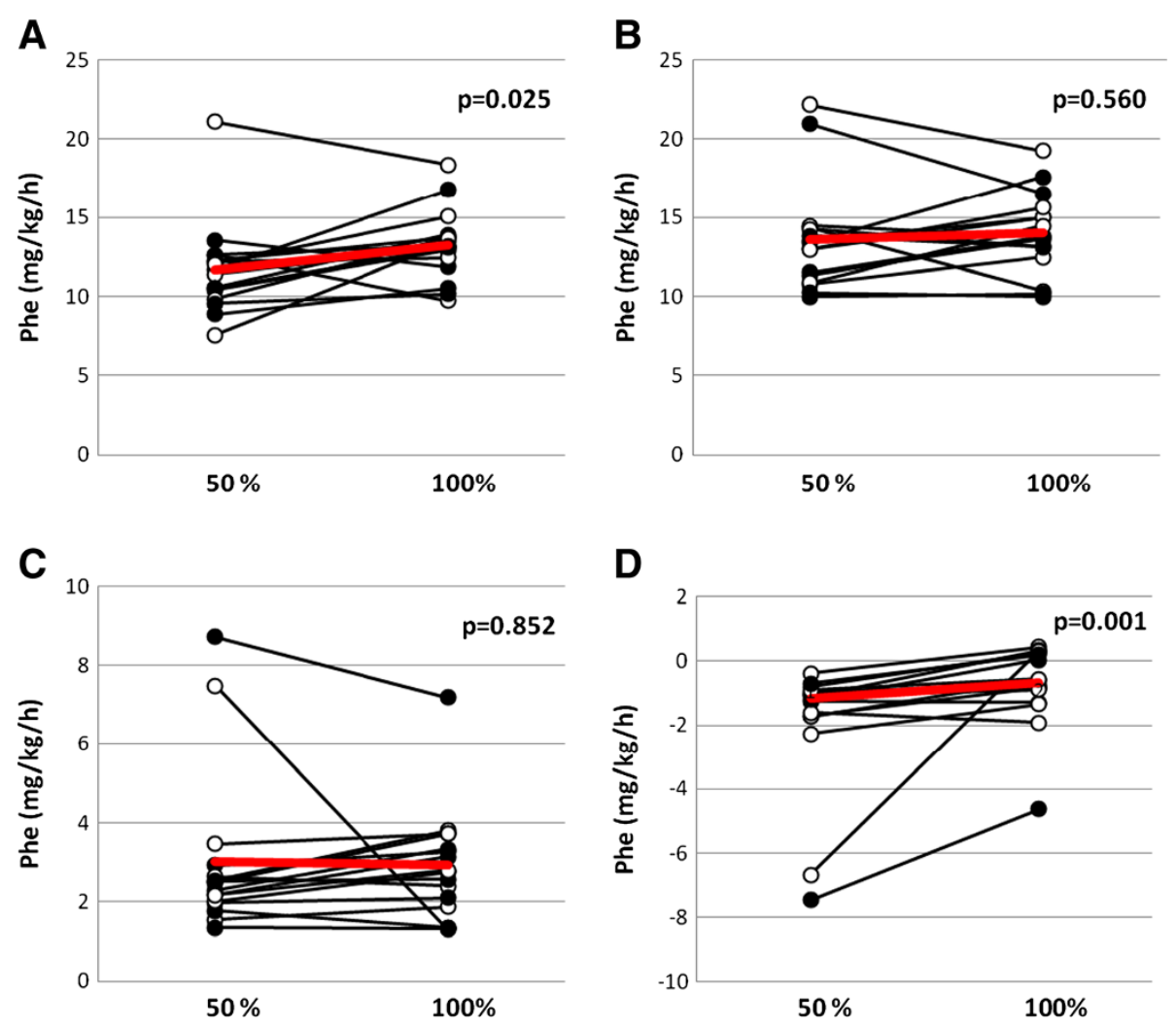

Figure 2 Whole body protein kinetics, calculated using a phenylalanine tracer, in critically ill mechanically ventilated neurosurgical patients $(n=16)$ who received normocaloric and hypocaloric intravenous nutrition in random order during two consecutive days. Patients were randomized to receive normocaloric before hypocaloric (filled symbols), or hypocaloric before normocaloric (open symbols) nutrition. (A) Whole-body protein synthesis; (B) whole-body protein degradation; (C) phenylalanine oxidation; (D) whole-body protein balance. $P$-values are for paired comparisons. Phe, phenylalanine. Red lines indicate mean values.

$50 \%$ or $100 \%$ of measured EE (see Figure 2 for measurements with a phenylalanine tracer). Whole-body protein synthesis was $12 \%$ lower when $50 \%$ of $\mathrm{EE}$ was given, $11.7 \pm 3.0$ versus $13.3 \pm 2.2 \mathrm{mg}$ phenylalanine/ $\mathrm{kg} / \mathrm{h}(P=0.025)$, whereas whole-body protein degradation was also unaltered at $13.6 \pm 3.5$ versus $14.0 \pm 2.6$ $\mathrm{mg}$ phenylalanine $/ \mathrm{kg} / \mathrm{h}(P=0.56)$. Whole-body protein oxidation was unaltered at $3.0 \pm 2.1$ versus $2.9 \pm 1.4 \mathrm{mg}$ phenylalanine $/ \mathrm{kg} / \mathrm{h}(P=0.85)$, but the difference in the whole-body synthesis rate resulted in a $60 \%$ difference in whole-body protein balance, with $-1.9 \pm 2.1$ versus $-0.7 \pm$ $1.3 \mathrm{mg}$ phenylalanine $/ \mathrm{kg} / \mathrm{h}(P=0.001$, Wilcoxon test $)$.

Figure 3 illustrates the results with a leucine tracer. The difference in whole-body protein balance remained at $-0.3 \pm 0.5$ compared to $0.6 \pm 0.5 \mathrm{mg}$ leucine $/ \mathrm{kg} / \mathrm{h}$ $(P<0.001)$ for PN of $50 \%$ and $100 \%$ of measured $\mathrm{EE}$, respectively, and simultaneously the whole-body protein oxidation was unaltered at $1.3 \pm 0.5$ versus $1.4 \pm$ $0.5 \mathrm{mg}$ leucine $/ \mathrm{kg} / \mathrm{h}(P=0.19)$. For whole-body synthesis and degradation the results were different; whole-body protein synthesis was unaltered at $20.7 \pm$ 4.1 versus $20.5 \pm 2.8 \mathrm{mg}$ leucine $/ \mathrm{kg} / \mathrm{h}(P=0.69)$, and so was whole-body protein degradation at $21.0 \pm 4.4$ versus $19.9 \pm 2.8 \mathrm{mg}$ leucine $/ \mathrm{kg} / \mathrm{h}(P=0.11)$.

\section{Discussion}

Whole-body protein kinetics were studied in patients in the neurosurgical ICU, who were sedated and on mechanical ventilation, and were receiving hypocaloric and normocaloric feeding by standard PN. The major finding was that full feeding resulted in a less negative or positive whole-body protein balance, and that simultaneously the amino acid oxidation was not different.

The study protocol using two consecutive days, during which patients received two different treatments, is an attractive option in studies of heterogenous patient groups, such as critically ill patients [17-19]. Due to randomization of the time order of treatments and comparability of patients' characteristics on the two days, we can assume that conditions outside the intervention were reasonably similar and therefore, that this enabled a fair comparison. The study of neurosurgical patients on mechanical ventilation also made indirect calorimetry applicable, as the oxygen fraction was low in all patients. 

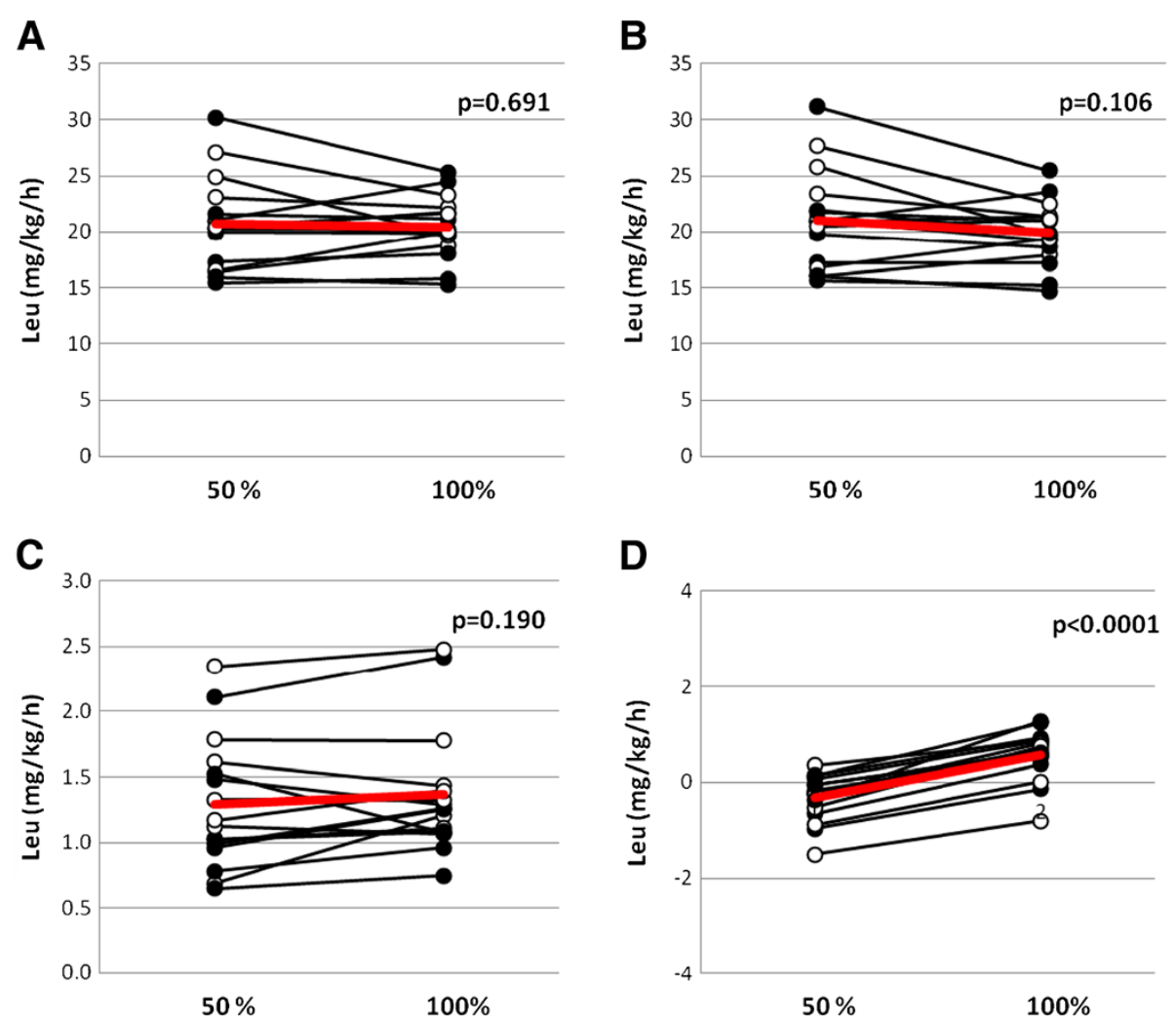

Figure 3 Whole body protein kinetics, calculated using a leucine tracer, in critically ill mechanically ventilated neurosurgical patients $(n=16)$ who received normocaloric and hypocaloric intravenous nutrition in random order during two consecutive days. Patients were randomized to receive normocaloric before hypocaloric (filled symbols), or hypocaloric before normocaloric (open symbols) nutrition. (A) Wholebody protein synthesis; (B) whole-body protein degradation; (C) leucine oxidation; and (D) whole-body protein balance. P-values are for paired comparisons. Leu, leucine. Red lines indicate mean values.

The study protocol focused on optimizing measurement conditions by means of (i) a homogenous group of patients, (ii) high probability of two comparable consecutive 24-hour periods, and (iii) full control over nutrition by the parenteral route. Naturally, these inclusion criteria limit the external validity of the study, but under these conditions, the nutrition made a difference for whole-body protein kinetics, which was not just a combusted caloric intake, as reflected by the amino acid oxidation. It is, however, beyond the scope of the study to speculate over the possible clinical relevance of this finding. Still, it is reasonable to conclude that the results demonstrate the usefulness of the applied technique and protocol, which suggests its use in studies in the future.

Measured EE determined the caloric supply, whereas the composition of the specific all-in-one formulation used determined the protein supply. The protein supply level was below the recommendation given in the European Society of Clinical Nutrition and Metabolism (ESPEN) guidelines [1]. An interesting observation is that the amino acid oxidation level was not different between the two levels of protein supply, which suggests that a protein supply of $1.07+0.15 \mathrm{~g}$ protein $/ \mathrm{kg} / 24 \mathrm{~h}$ was effectively utilized. Future studies will address the question of the optimal protein supply level [20].

In an earlier study including singular measurements in a small group of general ICU patients and of volunteers, we also used phenylalanine and leucine tracers in parallel [21]. The rationale for using parallel tracers was that existing literature on whole-body protein kinetics evaluated by these two tracers, tends to show a uniform result for the protein balance level, but the contributions from changes in whole-body protein synthesis and breakdown may be related to the amino acid tracer used [22]. Our pilot experience reproduced that finding. So, in the present study we continued to use parallel tracers and again found this difference. The phenylalanine tracer indicated a less negative whole-body protein balance when receiving $100 \%$ of EE related to a higher rate of wholebody protein synthesis, while the leucine tracer gave a similar result for whole-body protein balance, related to a tendency (not statistically significant) towards a lower rate of protein degradation.

The mechanism(s) behind the varying results obtained with the phenylalanine and leucine tracers is/are obscure. A possible explanation is the variation in representation in 
the precursor pools of individual organs by the two tracers. Phenylalanine probably better represents the liver, while leucine (or more correctly $\alpha$-keto-iso-caproate, which is used for the calculations) better represents skeletal muscle.

The generalizability of our data is limited due to: (i) the study population having narrow inclusion criteria, (ii) patients being on PN only, and (iii) the low nitrogento-calorie ratio in the commercially available formulation that was used. So, the difference between hypocaloric and normocaloric supply may be attributed to the administered caloric levels or to the protein (amino acid) levels, or a combination of the two. Clearly, further studies are needed to settle this point. The time course during the ICU stay, and the possibility of an adaptation period after changes in protein intake, are other issues that need to be addressed in the future.

The limitation related to the use of PN only constitutes a technical problem that should not be underestimated in critically ill patients, where the success rate of enteral feeding related to the prescribed dose or to nutritional target is most often low and unpredictable [23]. In the present and future studies, selection of patients on PN only, or patients on successful and stable enteral feeding, also will considerably limit external validity. Techniques and protocols that are generalizable to most critically ill patients being fed enterally, parenterally, or by a combination of the two, must be developed.

In the present study involving neurolosurgical ICU patients the observed EE level ranged from 19 to $31 \mathrm{kcal} /$ $\mathrm{kg} / 24 \mathrm{~h}$ (median 25) during the initial week of the ICU stay. In a general ICU population the values are often lower during the initial week of stay (range 14 to 34 $\mathrm{kcal} / \mathrm{kg} / 24 \mathrm{~h}$; median 21) as shown in a recent study [24]. It may be that the patient group in this study had a certain level of hypermetabolism (not severe), but we cannot confirm this as a factor that invalidates our results. Hypermetabolism is repeatedly reported in studies of neurosurgical critically ill patients [25]. The small but statistically significant difference in measured EE between pre-study and 50\% PN measurements may be interpreted as a sign of overfeeding before the study period, at least in some cases. The possibility of an insulin effect related to the higher caloric intake during the normocaloric feeding period was also considered. However, no such effect was detected.

\section{Conclusion}

In this pilot, whole-body protein kinetics were investigated in a selected group of critically ill patients in the neurosurgical ICU. Hypocaloric feeding was found to be associated with a more negative protein balance, but with unaltered amino acid oxidation, compared to normocaloric feeding. Overall the protein content of the feeding given was low, $0.53 \mathrm{~g}$ protein $/ \mathrm{kg} / 24 \mathrm{~h}$ and $1.07 \mathrm{~g}$ protein $/ \mathrm{kg} / 24 \mathrm{~h}$, respectively, in the two feeding protocols. The major finding of the study, which evaluated the nutritional support effect on critically ill patients, is the usefulness of the whole-body protein turnover technique, combined with a 48-hour protocol, when comparing two alternative feeding protocols in the individual patient.

\section{Key messages}

- Whole-body protein turnover measurement is a useful technique to elucidate the protein content of feeding in the critically ill.

- Full nutrition with a standard IV formula gives a better protein balance compared to hypocaloric feeding.

- A protein supply of $1.1 \mathrm{~g} / \mathrm{kg} /$ day as part of full feeding does not enhance amino acid oxidation, which would have been indicative of futile protein supply.

\section{Abbreviations}

endoRa: Endogenous rate of appearance; ESPEN: European Society of Clinical Nutrition and Metabolism; GCMS: Gas chromatography mass spectrometry; HPLC: High pressure liquid chromatography; IC: Indirect calorimetry; IV: Intravenous; kcal: Kilocalorie; KIC: Keto-iso-caproate; Ox: Oxidation rate; PN: Parenteral nutrition; Ra: Rate of appearance; Rd: Rate of disappearance; TPN: Total parenteral nutrition.

\section{Competing interests}

None of the authors have any competing interest to declare.

\section{Authors' contributions}

$A B, O R$, and JW: conception and design of the study, interpretation of data, finalizing manuscript. $A B$ and $B M B$ : acquisition of data. OR: analytical procedures and methods. $A B, O R$ and JW: calculations and manuscript preparation. All authors read and approved the final manuscript.

\section{Authors' information}

Agneta Berg, RNA PhD: Postdoctoral Fellow at the Division of Anaesthesiology at CLINTEC, Karolinska Institutet, and Head Nurse at Department of Neonatology Karolinska University Hospital, Huddinge; at the time of the study, nurse at the Department of Neurosurgery, Karolinska University Hospital, Solna.

Olav Rooyackers, PhD: Professor of Anesthesiology and Intensive Care Medicine at the Division of Anaesthesiology at CLINTEC, Karolinska Institutet. Bo-Michael Bellander, MD, PhD: Associate Professor of Neurosurgery at the Division of Neurosurgery at Clinical Neuroscience, Karolinska Institutet, and senior consultant at the Department of Neurosurgery, Karolinska University Hospital, Solna.

Jan Wernerman, MD, PhD: Professor of Anesthesiology and Intensive Care Medicine at the Division of Anaesthesiology at CLINTEC, Karolinska Institutet, and senior consultant at the Department of Anesthesiology and Intensive Care Medicine, Karolinska University Hospital Huddinge.

\section{Acknowledgements}

The authors would like to acknowledge the excellent nursing assistance from Viveka Gustafsson and Gunilla Herman, and the skilled technical assistance from Eva Nejman-Skog and Christina Hebert. The authors also thank Agneta Laveskog for performing the breath analyses. In addition the authors acknowledge the support and encouragement by the staff at the Neurosurgical ICU, in particular Helena Wadstein Gustafsson and Daniel Törnberg. Finally the authors want to acknowledge the excellent language editing by Judy Petersen. The study was supported by grants from the 
Swedish Medical Research Council (projects 04210 and 14244) and the Country Council of Stockholm (projects 502033 and 511126).

\section{Author details}

'Department of Anesthesiology and Intensive Care Medicine, K32, Karolinska University Hospital Huddinge, Stockholm 14186, Sweden. ${ }^{2}$ Department of Neurosurgery, Karolinska University Hospital Solna, at Karolinska Institutet, Stockholm, Sweden.

Received: 20 May 2013 Accepted: 15 July 2013

Published: 24 July 2013

\section{References}

1. Kreymann KG, Berger MM, Deutz NE, Hiesmayr M, Jolliet P, Kazandjiev G, Nitenberg G, van den Berghe G, Wernerman J, Ebner C, Hartl W, Heymann C, Spies C: ESPEN Guidelines on Enteral Nutrition: Intensive care. Clin Nutr 2006, 25:210-223.

2. Singer P, Berger MM, Van den Berghe G, Biolo G, Calder P, Forbes A, Griffiths R, Kreyman G, Leverve X, Pichard C: ESPEN Guidelines on Parenteral Nutrition: intensive care. Clin Nutr 2009, 28:387-400

3. McClave SA, Martindale RG, Vanek WW, McCarthy M, Roberts P, Taylor B, Ochoa JB, Napolitano L, Cresci G: Guidelines for the Provision and Assessment of Nutrition Support Therapy in the Adult Critically III Patient: Society of Critical Care Medicine (SCCM) and American Society for Parenteral and Enteral Nutrition (A.S.P.E.N.). JPEN J Parenter Enteral Nutr 2009, 33:277-316.

4. Kreymann G, DeLegge MH, Luft G, Hise ME, Zaloga GP: The ratio of energy expenditure to nitrogen loss in diverse patient groups-a systematic review. Clin Nutr 2012, 31:168-175.

5. Hoffer L, Bistrian BR: Appropriate protein provision in critical illness: a systematic and narrative review. Am J Clin Nutr 2012, 96:591-600.

6. Sauerwein HP, Serlie MJ: Optimal nutrition and its potential effect on survival in critically ill patients. Neth J Med 2010, 68:119-122

7. Ishibashi N, Plank LD, Sando K, Hill GL: Optimal protein requirements during the first 2 weeks after the onset of critical illness. Crit Care Med 1998, 26:1529-1535.

8. Arnold J, Campbell IT, Samuels TA, Devlin JC, Green CJ, Hipkin $\sqcup$, MacDonald IA, Scrimgeour CM, Smith K, Rennie MJ: Increased whole body protein breakdown predominates over increased whole body protein synthesis in multiple organ failure. Clin Sci (Lond) 1993, 84:655-661.

9. van Waardenburg DA, Deutz NE, Hoos MB, Jansen NJ, van Kreel BK, Vos GD, Wagenmakers AJ, Forget PP: Assessment of whole body protein metabolism in critically ill children: can we use the [15N]glycine single oral dose method? Clin Nutr 2004, 23:153-160.

10. Verbruggen SC, Coss-Bu J, Wu M, Schierbeek H, Joosten KF, Dhar A, van Goudoever JB, Castillo L: Current recommended parenteral protein intakes do not support protein synthesis in critically ill septic, insulinresistant adolescents with tight glucose control. Crit Care Med 2011, 39:2518-2525

11. Jahoor F, Desai M, Herndon DN, Wolfe RR: Dynamics of the protein metabolic response to burn injury. Metabolism 1988, 37:330-337.

12. Borsheim E, Chinkes DL, McEntire SJ, Rodriguez NR, Herndon DN, Suman OE: Whole body protein kinetics measured with a non-invasive method in severely burned children. Burns 2010, 36:1006-1012.

13. Vesali RF, Klaude M, Rooyackers OE, Tjäder I, Barle H, Wernerman J: Longitudinal pattern of glutamine/glutamate balance across the leg in long-stay intensive care unit patients. Clin Nutr 2002, 21:505-514.

14. Matthews DE, Schwarz HP, Yang RD, Motil KJ, Young VR, Bier DM: Relationship of plasma leucine and alpha-ketoisocaproate during a L-[1-13C]leucine infusion in man: a method for measuring human intracellular leucine tracer enrichment. Metabolism 1982, 31:1105-1112.

15. Allsop JR, Wolfe RR, Burke JF: Tracer priming the bicarbonate pool. J Appl Physiol 1978, 45:137-139.

16. Charlton MR, Adey DB, Nair KS: Evidence for a catabolic role of glucagon during an amino acid load. J Clin Invest 1996, 98:90-99.

17. Berg A, Bellander BM, Wanecek M, Gamrin L, Elving A, Rooyackers O, Ungerstedt $U$, Wernerman J: Intravenous glutamine supplementation to head trauma patients leaves cerebral glutamate concentration unaffected. Intensive Care Med 2006, 32:1741-1746.

18. Berg A, Bellander BM, Wanecek M, Norberg A, Ungerstedt $U$, Rooyackers $\mathrm{O}$, Wernerman J: The pattern of amino acid exchange across the brain is unaffected by intravenous glutamine supplementation in head trauma patients. Clin Nutr 2008, 27:816-821.

19. Berg A, Norberg A, Martling CR, Gamrin L, Rooyackers O, Wernerman J: Glutamine kinetics during intravenous glutamine supplementation in ICU patients on continuous renal replacement therapy. Intensive Care Med 2007, 33:660-666.

20. Weijs PJ, Wischmeyer PE: Optimizing energy and protein balance in the ICU. Curr Opin Clin Nutr Metab Care 2013, 16:194-201.

21. Rooyackers O, Kouchek-Zadeh R, Tjader I, Norberg A, Klaude M, Werneman $\mathrm{J}$ : Whole body protein turnover in mechanically ventilated ICU patients. Intensive Care Med 2012, 38:S130.

22. Tessari P, Barazzoni R, Zanetti M: Differences in estimates of forearm protein synthesis between leucine and phenylalanine tracers following unbalanced amino acid infusion. Metab Clin Exp 1999, 48:1564-1569.

23. Alberda C, Gramlich L, Jones N, Jeejeebhoy K, Day AG, Dhaliwal R, Heyland DK: The relationship between nutritional intake and clinical outcomes in critically ill patients: results of an international multicenter observational study. Intensive Care Med 2009, 35:1728-1737.

24. Sundstrom $\mathrm{M}$, Tjader I, Rooyackers $\mathrm{O}$, Wernerman J: Indirect calorimetry in mechanically ventilated patients. A systematic comparison of three instruments. Clin Nutr 2013, 32:118-121.

25. Borzotta AP, Pennings J, Papasadero B, Paxton J, Mardesic S, Borzotta R, Parrott A, Bledsoe F: Enteral versus parenteral nutrition after severe closed head injury. J Trauma 1994, 37:459-468.

doi:10.1186/cc12837

Cite this article as: Berg et al:: Whole body protein kinetics during hypocaloric and normocaloric feeding in critically ill patients. Critical Care 2013 17:R158.

\section{Submit your next manuscript to BioMed Central and take full advantage of:}

- Convenient online submission

- Thorough peer review

- No space constraints or color figure charges

- Immediate publication on acceptance

- Inclusion in PubMed, CAS, Scopus and Google Scholar

- Research which is freely available for redistribution

Submit your manuscript at www.biomedcentral.com/submit
C Biomed Central 